\title{
Article
}

\section{Distinct Mutational Profile of Lynch Syndrome Colorectal Cancers Diagnosed under Regular Colonoscopy Surveillance}

\author{
Aysel Ahadova ${ }^{1, *}$, Pauline Luise Pfuderer ${ }^{1}$, Maarit Ahtiainen ${ }^{2}{ }^{(D}$, Alexej Ballhausen ${ }^{1} \mathbb{D}$, Lena Bohaumilitzky ${ }^{1}$, \\ Svenja Kösegi ${ }^{1}$, Nico Müller ${ }^{1}$, Yee Lin Tang ${ }^{1}$, Kosima Kosmalla ${ }^{1}$, Johannes Witt ${ }^{1}$, Volker Endris ${ }^{3}{ }^{10}$, \\ Albrecht Stenzinger ${ }^{3}$, Magnus von Knebel Doeberitz ${ }^{1}$, Hendrik Bläker ${ }^{4}$, Laura Renkonen-Sinisalo ${ }^{5}$, \\ Anna Lepistö ${ }^{5}$, Jan Böhm ${ }^{6}$, Jukka-Pekka Mecklin ${ }^{2,7,+}$, Toni T. Seppälä ${ }^{5,8, *,+}$ (i) and Matthias Kloor ${ }^{1,+}$
}

check for updates

Citation: Ahadova, A.; Pfuderer, P.L.; Ahtiainen, M.; Ballhausen, A.; Bohaumilitzky, L.; Kösegi, S.; Müller, N.; Tang, Y.L.; Kosmalla, K.; Witt, J.; et al. Distinct Mutational Profile of Lynch Syndrome Colorectal Cancers Diagnosed under Regular Colonoscopy Surveillance. J. Clin. Med. 2021, 10, 2458. https://doi.org/ $10.3390 / \mathrm{jcm} 10112458$

Academic Editor: Roberta Gafà

Received: 31 March 2021

Accepted: 26 May 2021

Published: 1 June 2021

Publisher's Note: MDPI stays neutral with regard to jurisdictional claims in published maps and institutional affiliations.

Copyright: (c) 2021 by the authors. Licensee MDPI, Basel, Switzerland. This article is an open access article distributed under the terms and conditions of the Creative Commons Attribution (CC BY) license (https:/ / creativecommons.org/licenses/by/ $4.0 /)$.
1 Department of Applied Tumour Biology, Institute of Pathology, University Hospital Heidelberg, Cooperation Unit Applied Tumour Biology, German Cancer Research Center (DKFZ), 69120 Heidelberg, Germany; paulinepfuderer@gmail.com (P.L.P.); alexej.ballhausen@gmail.com (A.B.); 1.bohaumilitzky@dkfz-heidelberg.de (L.B.); svenja.koesegi@web.de (S.K.); nico.mueller@stud.uni-heidelberg.de (N.M.); yee_lin_tang@ttsh.com.sg (Y.L.T.); kosima.kosmalla@gmx.de (K.K.); johannes.witt.96@googlemail.com (J.W.); magnus.knebel-doeberitz@med.uni-heidelberg.de (M.v.K.D.); Matthias.kloor@med.uni-heidelberg.de (M.K.)

2 Department of Education and Research, Central Finland Central Hospital, 40620 Jyväskylä, Finland; maarit.ahtiainen@ksshp.fi (M.A.); jukka-pekka.mecklin@ksshp.fi (J.-P.M.)

3 Department of General Pathology, Institute of Pathology, University Hospital Heidelberg, 69120 Heidelberg, Germany; volker.endris@med.uni-heidelberg.de (V.E.); albrecht.stenzinger@med.uni-heidelberg.de (A.S.)

4 Institute of Pathology, University Hospital Leipzig, 04103 Leipzig, Germany; hendrik.blaeker@medizin.uni-leipzig.de

5 Department of Gastrointestinal Surgery, Helsinki University Hospital, 00290 Helsinki, Finland; laura.renkonen-sinisalo@hus.fi (L.R.-S.); anna.lepisto@hus.fi (A.L.)

6 Department of Pathology, Central Finland Central Hospital, 40620 Jyväskylä, Finland; jan.bohm@ksshp.fi

7 Faculty of Sports and Health Sciences, University of Jyväskylä, 40014 Jyväskylä, Finland

8 Department of Surgical Oncology, Johns Hopkins University, Baltimore, MD 21287, USA

* Correspondence: aysel.ahadova@med.uni-heidelberg.de (A.A.); toni.seppala@fimnet.fi (T.T.S.)

+ These authors contributed equally to this work.

Abstract: Regular colonoscopy even with short intervals does not prevent all colorectal cancers (CRC) in Lynch syndrome (LS). In the present study, we asked whether cancers detected under regular colonoscopy surveillance (incident cancers) are phenotypically different from cancers detected at first colonoscopy (prevalent cancers). We analyzed clinical, histological, immunological and mutational characteristics, including panel sequencing and high-throughput coding microsatellite (cMS) analysis, in 28 incident and 67 prevalent LS CRCs $(n$ total $=95)$. Incident cancers presented with lower UICC and $\mathrm{T}$ stage compared to prevalent cancers $(p<0.0005)$. The majority of incident cancers $(21 / 28)$ were detected after previous colonoscopy without any pathological findings. On the molecular level, incident cancers presented with a significantly lower KRAS codon $12 / 13(1 / 23,4.3 \%$ vs. $11 / 21,52 \%$; $p=0.0005)$ and pathogenic TP53 mutation frequency $(0 / 17,0 \%$ vs. $7 / 21,33.3 \% ; p=0.0108$, ) compared to prevalent cancers; $10 / 17$ (58.8\%) incident cancers harbored one or more truncating APC mutations, all showing mutational signatures of mismatch repair (MMR) deficiency. The proportion of MMR deficiency-related mutational events was significantly higher in incident compared to prevalent CRC $(p=0.018)$. In conclusion, our study identifies a set of features indicative of biological differences between incident and prevalent cancers in LS, which should further be monitored in prospective LS screening studies to guide towards optimized prevention protocols.

Keywords: Lynch syndrome; colorectal cancer; carcinogenesis; cancer prevention; colonoscopy screening; incident cancer; microsatellite instability; mismatch repair deficiency; mutational profiling 


\section{Introduction}

Individuals with Lynch syndrome (LS), the most common hereditary colorectal cancer (CRC) syndrome, have a 50\% lifetime risk of developing CRC [1]. LS is caused by pathogenic variants in one of the mismatch repair (MMR) genes MLH1, MSH2, MSH6 or PMS2 [2].

Due to loss of MMR function, base mismatches occurring during DNA replication remain uncorrected and lead to insertion/deletion mutations (indels), particularly at repetitive sequences (microsatellites). Thus, cancers arising in LS exhibit the molecular phenotype of microsatellite instability (MSI). When indel mutations hit coding microsatellites (cMS), two possible biologically relevant consequences follow: first, mutations at cMS can lead to inactivation of tumor suppressor genes, contributing to carcinogenesis [3]; second, such mutations shift the reading frame and lead to generation of frameshift peptides (FSP), rendering MSI tumors highly immunogenic [4-8].

Surveillance by colonoscopy is a recommended preventive measure in LS mutation carriers $[9,10]$. Colonoscopy has been shown to decrease CRC incidence and mortality [11-14]. However, in contrast to the general population [15-17], a substantial proportion of LS mutation carriers develop "incident carcinomas", or "post-colonoscopy CRC" $[11,18-24]$ despite regular colonoscopy. In fact, recent prospective studies $[22,23,25]$ collecting evidence from patients under surveillance demonstrated no difference in cumulative cancer incidence up to the age of 70 years when compared to studies on retrospective cohorts without surveillance [26-29].

In parallel to technical, colonoscopy quality-related explanations for the high incidence of CRC under surveillance in LS, biological explanations have been proposed, suggesting that incident cancers may develop from a precursor lesion more difficult to detect than polypoid adenomas, such as MMR-deficient crypts [30-33]. MMR-deficient crypts are morphologically indistinguishable from normal colonic crypts, but they lack the MMR protein expression on the molecular level [33-35]. Like MSI CRC, MMR-deficient crypts also present with MSI and MSI-induced tumor suppressor gene mutations as a direct consequence of MSI, thus possessing the theoretical potential to develop into cancer. However, direct evidence of such a progression is not trivial to obtain, as no technical means to monitor MMR-deficient crypts exist.

In contrast to clinical characteristics [36], the molecular properties of incident cancers have not been characterized so far. We aimed to analyze the molecular characteristics of incident LS CRCs diagnosed under regular surveillance and to compare them with prevalent LS CRCs diagnosed at first colonoscopy or prior to surveillance.

\section{Materials and Methods}

\subsection{Patients and Tumor Samples}

Carriers of pathogenic MMR variants that underwent colonoscopy surveillance with a planned 3-year interval ( 2 years if previous CRC) were identified from the prospectively maintained Finnish Lynch syndrome registry. Available formalin-fixed paraffin-embedded (FFPE) tumor blocks from patients who developed incident $(n=28)$ and prevalent $(n=7)$ cancers were collected from the Lynch Syndrome Biobank at the Central Finland Central Hospital, Jyväskylä, Finland. FFPE tumor tissue blocks from LS patients with prevalent CRC $(n=60)$ were collected at the Department of Applied Tumor Biology, Institute of Pathology, University Hospital Heidelberg as part of the German HNPCC Consortium. Prevalent cancers were diagnosed either at first surveillance colonoscopy or prior to surveillance initiation due to symptoms. All patients provided informed and written consent, and the study was approved by the Institutional Ethics Committee (S-583/2016). Research permission was granted by the National Authority of Health and Welfare (former TEO Dnro 1272/044/07 and Valvira Dnro 10741/06.01.03.01/2015). The DNeasy FFPE Kit was used for the isolation of tumor DNA after manual microdissection from 5-6 $\mu \mathrm{m}$ thick hematoxylin/eosin (HE)-stained FFPE tissue sections (Qiagen, Germany). 


\subsection{Histopathology Analysis}

HE-stained tumor tissue sections underwent histopathological analysis by two pathologists. All tumors, from which a tumor tissue section was available, were analyzed for grade and histology features. All tumors, for which the transition from normal mucosa to invasive cancer was present on the tissue sections, were assessed for their growth pattern. In addition, presence of MMR-deficient crypts was evaluated in sections containing tumor-adjacent normal mucosa and stained for the respective MMR protein (see Section 2.4).

For the assessment of tumor growth pattern, tumors were classified in three major groups: "polypoid" (corresponding to Type Ip of the Paris classification [37]), "flat" (corresponding to IIa or IIb of the Paris classification) and "depressed" (corresponding to IIc of the Paris classification). A polypoid growth pattern was defined by a tumor having fibrovascular cores and a vertical growth that is more prominent than the transverse/horizontal growth, whereas a flat growth pattern had a more prominent transverse/horizontal growth. Both polypoid and flat growth patterns were defined as tumors that were elevated above the level of the mucosa, whereas a depressed growth pattern was defined as tumors that have the bulk of the tumor located below the level of the mucosa.

\subsection{Mutation Analysis}

Mutational analysis was performed in tumor samples, from which DNA in sufficient amount and quality could be isolated. Targeted next generation sequencing was performed as described previously on an Ion Torrent S5XL/Prime sequencer using a custom 180 amplicon panel (CRC panel) encompassing mutation HotSpot regions in 30 genes [38-41]. Data analysis was performed using the Ion Torrent Suite Software (version 5.10). Only variants with an allele frequency $>5 \%$ and minimum coverage $>100$ reads were taken into account. Variant annotation was performed using Annovar (hg19 genome) [40]. Annotations included information about nucleotide and amino acid changes of RefSeq annotated genes, COSMIC and dbSNP entries as well as detection of possible splice site mutations. For data interpretation and verification, the aligned reads were visualized using the IGV browser (Broad Institute) [41].

MSI analysis was performed using a sensitive and specific mononucleotide marker panel (BAT25, BAT26 and CAT25) as described previously [42]. cMS mutation analysis was performed using a novel high-throughput method for quantitative fragment length analysis with 5-carboxyfluorescein-labeled primers specific for a set of 22 cMS [43] (see Supplementary Table S1 for details), which were selected based on two criteria: evidence of a functional driver role of mutation [43] and potential significance as a source of immunogenic frameshift peptide neoantigens [44]. PCR products were visualized on an ABI3130xl sequencer, and the obtained results were processed using the ReFrame algorithm to obtain quantitative estimation of the frequency of the mutant alleles in tumor specimens [45]. Mutation status of B2M was determined by Sanger sequencing as described previously [46]. The obtained mutational data for incident cancers were compared with the mutational data for prevalent cancers published in our previous reports [32,38,45].

\subsection{Immunohistochemical Staining and Quantification of T Cell Density}

FFPE tissue sections $(2-3 \mu \mathrm{m})$ were used for immunohistochemical staining [47,48]. Briefly, sections were deparaffinized and rehydrated and subsequently stained according to standard protocols. The following primary antibodies were used: anti-CD3 (clone PS1, dilution 1:100, Abcam, Cambridge, UK); anti-MLH1 (clone G168-15, dilution 1:300, BD Pharmingen, Heidelberg, Germany); and anti-MSH2 (clone FE11, dilution 1:100, Calbiochem, Darmstadt, Germany). As a secondary antibody, the biotinylated anti-mouse/anti-rabbit antibody (Vector Laboratories) was used at 1:100 dilution. Staining was visualized using the Vectastatin elite ABC detection system (Vector Laboratories, Burlingame, CA, USA) and 3,3'-diaminobenzidine (Dako North America Inc., Carpinteria, CA, USA) as a chromogen. For counterstaining hematoxylin was used. Stained sections were scanned using 
NanoZoomer S210 slide scanner (Hamamatsu, Hamamatsu, Japan) and viewed using NDP.view2 Viewing Software (Hamamatsu). Four random $0.25 \mathrm{~mm}^{2}$ square regions were drawn in the tumor tissue and positive cells in each region were counted using the QuPath Software, giving mean values per $0.25 \mathrm{~mm}^{2}$.

\subsection{Statistical Calculations}

Statistical significance of differences between binary variables was calculated using Pearson's chi-squared test or Fisher's exact test. Statistical significance of the association of growth pattern with time since last colonoscopy was analyzed by Kruskal-Wallis test using GraphPad Prism (V6 Version 6.07, GraphPad Software Inc., La Jolla, CA, USA.) Statistical significance of differences in mutation frequencies of cMS genes, as well as significance of differences in immune infiltration, was calculated using two-sided Wilcoxon Rank Sum test (Mann-Whitney test). Correction for multiple testing was performed using BenjaminiHochberg procedure. $p$ values smaller than 0.05 were considered statistically significant. All scripts were written in R [49], version 3.6.0, using the R Studio environment [50]. All $95 \%$ confidence intervals $(\mathrm{CI})$ were calculated with modified Wald method.

\section{Results}

\subsection{Clinical Characteristics}

Clinical data and tumor specimens $(n=28)$ were collected from 27 LS patients who developed incident CRC during the 2-3-yearly preventive colonoscopy surveillance (23 MLH1 and 4 MSH2 carriers, 15 females and 12 males). Sixty-seven tumors from LS patients diagnosed with CRC as prevalent cancers were used as a comparison group. Median age at diagnosis was not significantly different between patients with incident and with prevalent cancer (54.4 vs. 50.0 years, $p>0.05)$. Nineteen out of $28(68 \%)$ incident and 33 out of $49(67 \%)$ prevalent cancers with information on tumor localization were localized in the proximal colon. Nine out of 28 tumors arose in patients with a history of previous CRC, 3 patients had other GI cancer and 10 patients had a previous non-GI cancer (endometrium, prostate, ureter, brain). The clinical parameters of incident cancers are summarized in Table 1.

Table 1. Clinical characteristics of patients with incident CRC.

\begin{tabular}{|c|c|c|c|c|c|c|c|c|c|c|c|c|}
\hline Patient & $\begin{array}{l}\text { Age at } \\
\text { Diag- } \\
\text { nosis }\end{array}$ & Gender & Location & $\begin{array}{l}\text { TNM } \\
\text { Stage }\end{array}$ & $\begin{array}{l}\text { UICC } \\
\text { Stage }\end{array}$ & Gene & $\begin{array}{l}\text { Age at } \\
\text { Last FU }\end{array}$ & $\begin{array}{l}\text { Age at } \\
\text { Death }\end{array}$ & $\begin{array}{c}\text { Cause of } \\
\text { Death }\end{array}$ & $\begin{array}{l}\text { Months } \\
\text { Since Last } \\
\text { Colonoscopy }\end{array}$ & $\begin{array}{c}\text { Reason of } \\
\text { Examina- } \\
\text { tion }\end{array}$ & $\begin{array}{c}\begin{array}{c}\text { Finding at } \\
\text { Last } \\
\text { Colonoscopy * }\end{array} \\
\text { * }\end{array}$ \\
\hline 1 & 54.6 & M & $\begin{array}{l}\text { splenic } \\
\text { flexure }\end{array}$ & T2N0M0 & I & MLH1 & 62.9 & & & 21.0 & symptoms & 0 \\
\hline 2 & 61.7 & $\mathrm{~F}$ & ascendens & T1N0M0 & I & MLH1 & 76.5 & & & 20.3 & follow-up & $\begin{array}{l}\text { advanced } \\
\text { adenoma }\end{array}$ \\
\hline 3 & 44.2 & M & descendens & Dukes A & I & MLH1 & 55.1 & & & 36.0 & follow-up & $\begin{array}{l}\text { adenoma with } \\
\text { LG dysplasia }\end{array}$ \\
\hline 4 & 69.7 & $\mathrm{~F}$ & sigmoid & T1N0M0 & I & MSH2 & 74.9 & 75.1 & $\begin{array}{l}\text { cardiac in- } \\
\text { sufficiency }\end{array}$ & 7.3 & follow-up & $\begin{array}{l}\text { advanced } \\
\text { adenoma }\end{array}$ \\
\hline 5 & 63.1 & $\mathrm{~F}$ & tranverse & T3N0M0 & II & MSH2 & 72.6 & 72.6 & $\begin{array}{c}\text { pancreatic } \\
\text { cancer }\end{array}$ & 25.0 & follow-up & 0 \\
\hline 6 & 70.5 & M & sigmoid & TisNxM0 & 0 & MLH1 & 78.4 & & & 24.5 & follow-up & 0 \\
\hline 7 & 35.5 & M & caecum & T3N1M0 & III & MLH1 & 44.3 & 44.3 & $\begin{array}{l}\text { gastric } \\
\text { cancer }\end{array}$ & 28.0 & symptoms & 0 \\
\hline 8 & 57.3 & F & sigmoid & T3N0M0 & II & MLH1 & 63.3 & & & 30.0 & follow-up & 0 \\
\hline 9 & 54.5 & $\mathrm{~F}$ & caecum & T2N0M0 & I & MLH1 & 63.4 & 63.4 & CRC & 31.2 & follow-up & 0 \\
\hline 10 & 71.6 & $\mathrm{~F}$ & rectum & T2N0M0 & I & MLH1 & 75.1 & 75.1 & $\begin{array}{l}\text { biliary tract } \\
\text { cancer }\end{array}$ & 24.0 & follow-up & 0 \\
\hline 11 & 41.7 & $\mathrm{~F}$ & descendens & T3N2M0 & III & MLH1 & 44.7 & 44.7 & CRC & 23.0 & symptoms & 0 \\
\hline 12 & 43.6 & $\mathrm{~F}$ & ascendens & T1N0M0 & I & MLH1 & 57.5 & 57.5 & $\begin{array}{l}\text { breast } \\
\text { cancer }\end{array}$ & 26.0 & follow-up & 0 \\
\hline 13 & 41.7 & $\mathrm{~F}$ & tranverse & T1N0M0 & I & MLH1 & 50.1 & & & 26.0 & follow-up & $\begin{array}{l}\text { adenoma with } \\
\text { LG dysplasia }\end{array}$ \\
\hline
\end{tabular}


Table 1. Cont.

\begin{tabular}{|c|c|c|c|c|c|c|c|c|c|c|c|c|}
\hline Patient & $\begin{array}{l}\text { Age at } \\
\text { Diag- } \\
\text { nosis }\end{array}$ & Gender & Location & $\begin{array}{l}\text { TNM } \\
\text { Stage }\end{array}$ & $\begin{array}{l}\text { UICC } \\
\text { Stage }\end{array}$ & Gene & $\begin{array}{l}\text { Age at } \\
\text { Last FU }\end{array}$ & $\begin{array}{l}\text { Age at } \\
\text { Death }\end{array}$ & $\begin{array}{c}\text { Cause of } \\
\text { Death }\end{array}$ & $\begin{array}{l}\text { Months } \\
\text { Since Last } \\
\text { Colonoscopy }\end{array}$ & $\begin{array}{c}\text { Reason of } \\
\text { Examina- } \\
\text { tion }\end{array}$ & $\begin{array}{c}\begin{array}{c}\text { Finding at } \\
\text { Last } \\
\text { Colonoscopy }\end{array} \\
\text { * }\end{array}$ \\
\hline 14 & 42.4 & $\mathrm{~F}$ & tranverse & T3N0M0 & II & MLH1 & 48.8 & 48.8 & $\begin{array}{l}\text { pancreatic } \\
\text { cancer }\end{array}$ & 24.4 & follow-up & 0 \\
\hline 15 & 71.5 & M & ascendens & T2N0M0 & I & MSH2 & 84.1 & & & 36.0 & follow-up & $\begin{array}{l}\text { adenoma with } \\
\text { LG dysplasia }\end{array}$ \\
\hline 16 & 43.6 & M & tranverse & T3N0M0 & II & MLH1 & 53.9 & 53.9 & $\begin{array}{l}\text { another } \\
\text { CRC }\end{array}$ & 26.0 & follow-up & 0 \\
\hline 17 & 71.9 & F & caecum & T2N0M0 & I & MLH1 & 81.4 & 81.4 & pneumonia & 29.0 & follow-up & 0 \\
\hline 18 & 69.0 & $\mathrm{~F}$ & caecum & T2N0M0 & I & MSH2 & 69.0 & 69.0 & $\begin{array}{l}\text { postoperative } \\
\text { complica- } \\
\text { tion }\end{array}$ & 37.7 & symptoms & 0 \\
\hline 19 & 42.0 & $\mathrm{~F}$ & caecum & T1N0M0 & I & MLH1 & 58.2 & & & 39.5 & follow-up & 0 \\
\hline 20 & 35.1 & M & caecum & Dukes B & II & MLH1 & 64.4 & & & 37.6 & follow-up & 0 \\
\hline 21.a & 54.2 & $\mathrm{~F}$ & ascendens & T2N0M0 & I & MLH1 & 63.3 & & & 30.1 & follow-up & 0 \\
\hline 21.b & 56.8 & $\mathrm{~F}$ & sigmoid & T3N0M0 & II & MLH1 & 63.3 & & & 28.8 & follow-up & 0 \\
\hline 22 & 54.2 & M & ascendens & T3N0M0 & II & MLH1 & 63.4 & 65.0 & $\begin{array}{l}\text { CUP (brain. } \\
\text { lung) }\end{array}$ & 18.0 & follow-up & $\begin{array}{l}\text { adenoma with } \\
\text { LG dysplasia }\end{array}$ \\
\hline 23 & 53.8 & M & ascendens & T2N0M0 & I & MLH1 & 58.8 & & & 16.4 & follow-up & $\begin{array}{c}\text { adenoma with } \\
\text { LG dysplasia }\end{array}$ \\
\hline 24 & 82.8 & M & descendens & T2N0M0 & I & MLH1 & 85.1 & & & 24.6 & follow-up & 0 \\
\hline 25 & 55.0 & $\mathrm{~F}$ & caecum & T1N0M0 & I & MLH1 & 66.4 & & & 39.1 & follow-up & 0 \\
\hline 26 & 43.5 & M & caecum & T2N0M0 & I & MLH1 & 52.5 & & & 36.2 & follow-up & 0 \\
\hline 27 & 27.2 & M & caecum & T2N0M0 & I & MLH1 & 42.9 & & & 37.9 & follow-up & 0 \\
\hline
\end{tabular}

CRC—colorectal cancers, M-male, F-female, LG—low grade, CUP—carcinoma with unknown primary, UICC—Union for International Cancer Control. *-Finding at last colonoscopy column refers to the previous colonoscopy before cancer diagnosis. Advanced adenoma was defined as adenoma $>1 \mathrm{~cm}$ and/or with villous features and/or with high-grade dysplasia.

The median duration of follow-up was 8.9 years (range: $0.0-29.3$ years). Twelve patients with incident cancers died during follow-up due to different reasons. Three of the 12 deceased patients died due to CRC: One patient (\#11) died from a symptomatic CRC that was diagnosed only two years after previous uneventful colonoscopy. Patient \#16 died from another, metachronous, CRC that was diagnosed after 6 years of not attending scheduled colonoscopies. Patient \#9 developed CRC liver metastases 7 years after the operation of a T2N0 caecum cancer, though no other primary tumor was found (Table 1).

Incident cancers presented with lower UICC stage compared to prevalent cancers ( $p=0.0002)$; the majority of incident cancers were stage I, whereas the majority of prevalent cancers were stage II tumors (Figure 1A). T stage of incident cancers was significantly lower than prevalent cancers $(p=0.00004)$, and no T4 lesions were identified among incident cancers (Figure 1B). Except for one tumor identified as a polyp (Table 1, \#6) and treated by polypectomy, all colonic incident tumors were identified as invasive adenocarcinomas and treated by surgery. In addition, one rectum cancer (Table 1,\#10) was treated by local surgical excision.

The median time since last colonoscopy in patients under surveillance was 27 months (range: 7.3-39.5 months). Time since last colonoscopy did not correlate with the stage of tumor (Supplementary Figure S1). The majority of incident CRCs developed after a colonoscopy in which no lesions were detected (21/28, 75.0\%, 95\% CI: 56.4-87.6\%, Table 1, Figure 1C). All performed colonoscopies were successful and of high quality, with complete examination reaching the remaining colon length and bowel preparation enabling the visualization of the entire mucosal surface. 

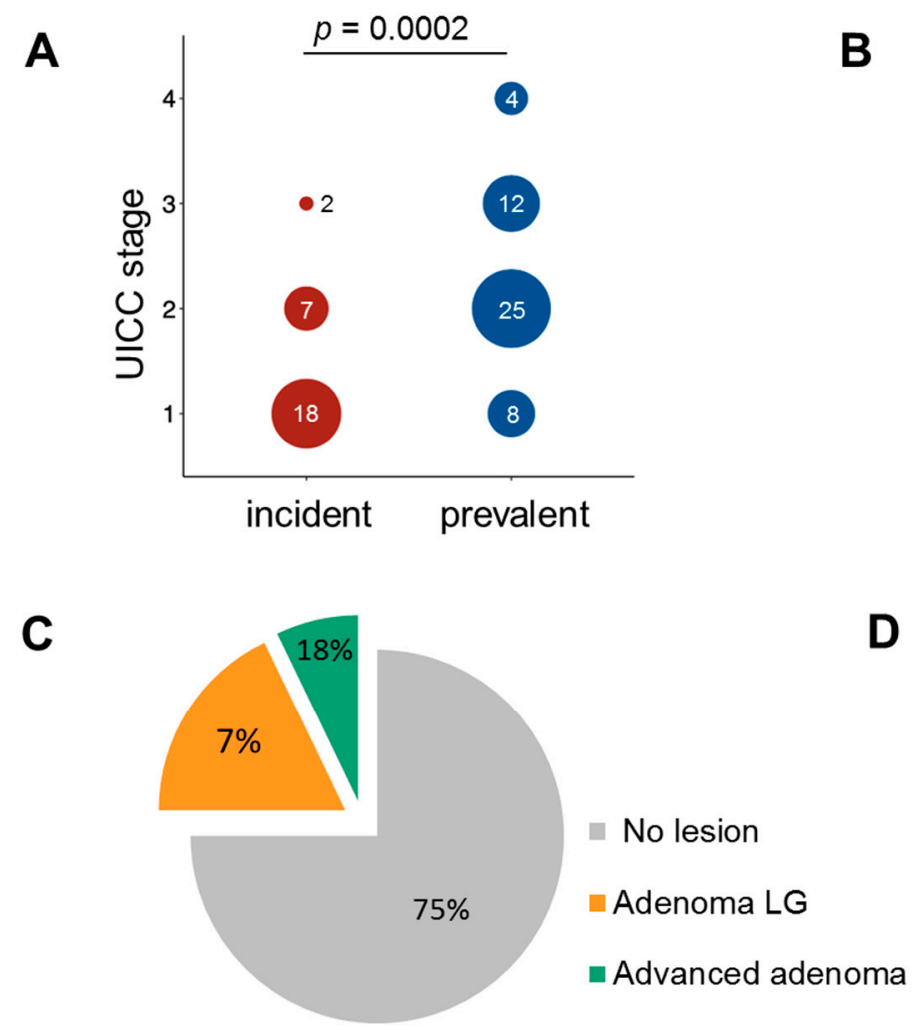

B
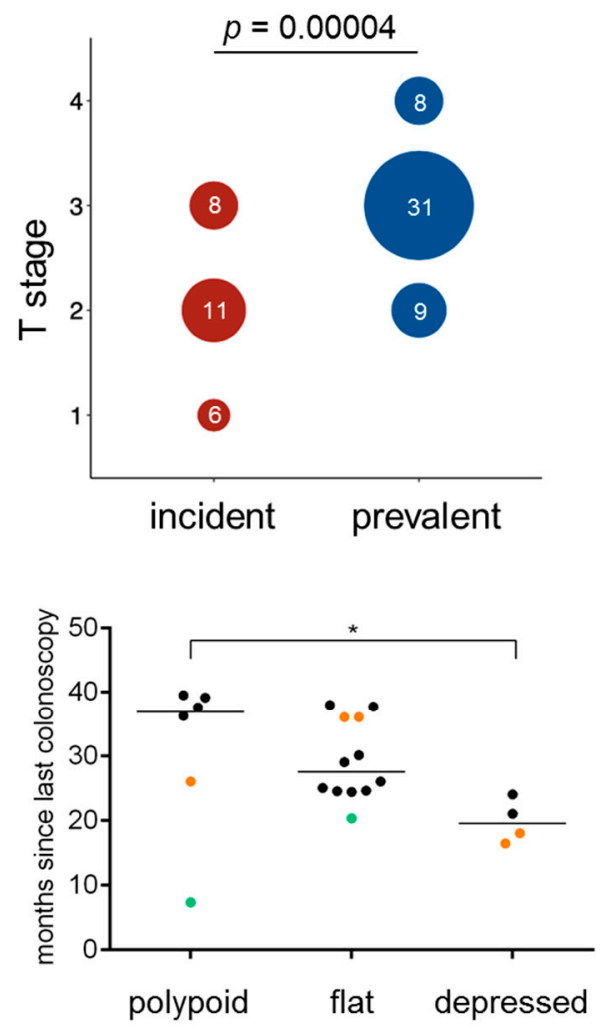

Figure 1. Clinical characteristics of incident cancers. (A,B) Distribution of UICC stage among incident and prevalent tumors. Tumors identified under surveillance have significantly lower UICC stage (A) and T stage (B) compared to tumors identified outside of surveillance. (C) Findings at previous colonoscopy in patients with incident cancers. The majority of patients with incident cancers did not present with any lesion at previous colonoscopy examination. (D) Association of histological growth pattern in incident cancers with time since last colonoscopy (Kruskal-Wallis test, $p<0.05$ indicated by an asterisk). Green dots mark the tumors preceded by a colonoscopy identifying an advanced adenoma, orange dots mark the tumors preceded by a colonoscopy identifying an adenoma with LG dysplasia, black dots mark the tumors preceded by a colonoscopy without identification of pathological lesions. LG-low grade; UICC - Union for International Cancer Control.

\subsection{Histopathology of Incident Cancers}

Representative HE and immunohistochemistry sections of the incident cancers were examined for microscopic pattern of tumor growth, degree of differentiation and presence of MMR-deficient crypts (Supplementary Table S2).

Among the 22 cases assessable for the tumor growth pattern, 12 showed a flat (55.5\%), $6(27.3 \%)$ showed a polypoid and $4(18.2 \%)$ showed a depressed growth pattern. All tumors showed at least a moderate degree of differentiation, with 16/28 (57.1\%) of them exhibiting mucinous components. Among 37 prevalent cancers analyzable for growth pattern, 5 showed a flat $(13.5 \%), 15(40.5 \%)$ showed a polypoid and $17(45.9 \%)$ showed a depressed growth pattern (Supplementary Table S3). The proportion of tumors with mucinous components was $35.1 \%(20 / 57)$ in prevalent cancers. When restricted to MLH1 patients only, the proportion of tumors with a mucinous component was significantly higher in incident cancer $(13 / 24,54.16 \%)$ compared to prevalent ones $(4 / 24,16.6 \% ; p=0.0145)$. Among incident cancers, the median time since last colonoscopy differed significantly $(p<0.05)$ between tumors with different histological growth pattern (median time since last colonoscopy 36.9/27.5/19.5 months in incident cancers with polypoid/flat/depressed growth pattern, respectively; Figure 1D). Interestingly, the only polypoid tumor with a short time since last colonoscopy was preceded by an advanced adenoma at previous colonoscopy (Figure 1D).

MMR-deficient crypts were present in two of the incident cancers: in both cases, these MMR-deficient crypts were present adjacent to areas of high-grade dysplasia/carcinoma in 
situ (Table 1, Patient \#6, Figure 2A and Table 1, Patient \#22, Figure 2B). The MMR-deficient crypt in Patient \#22 also showed pronounced immune infiltration (Figure 2B).
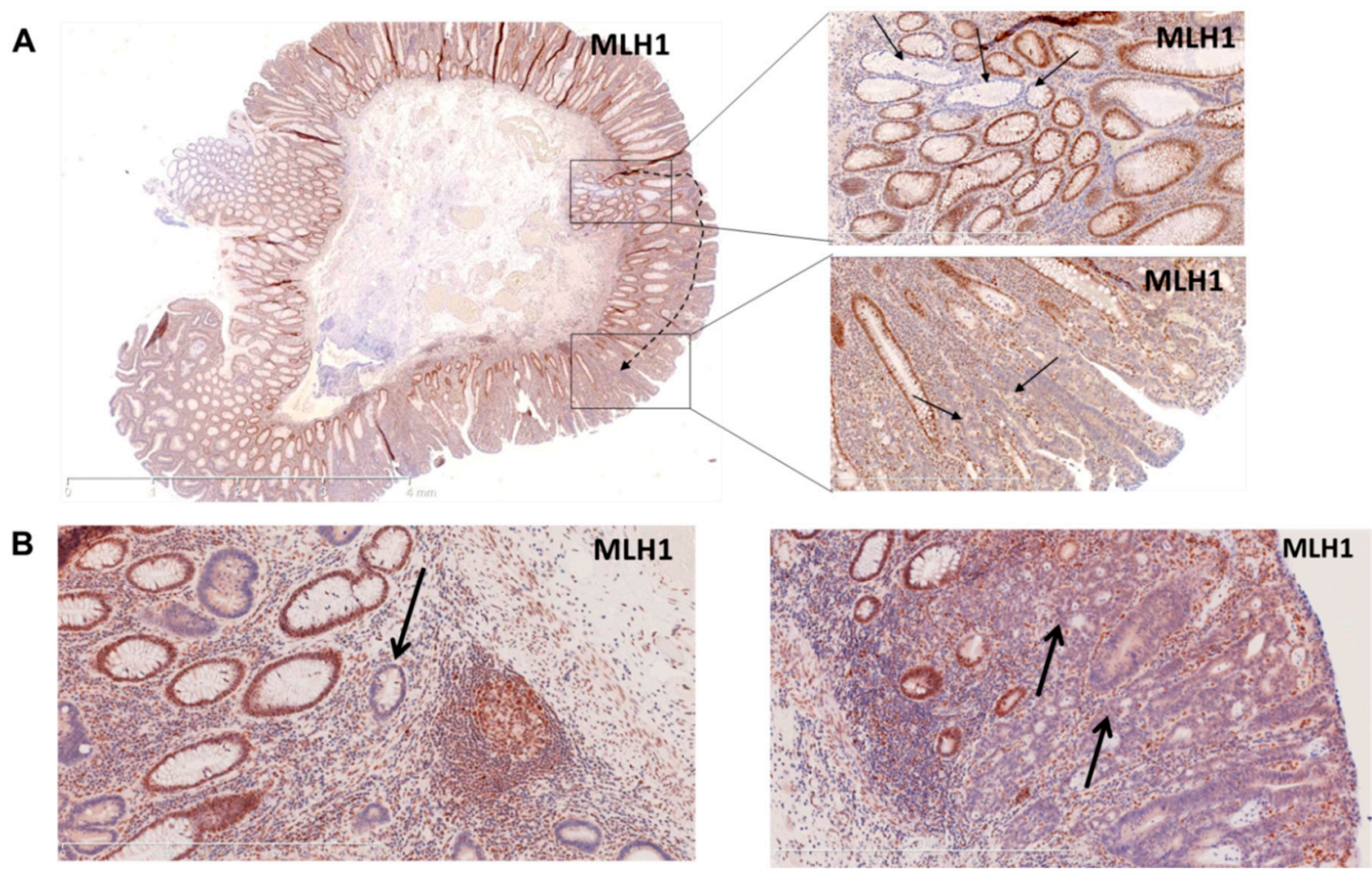

Figure 2. Histology images of tumor specimens with MMR-deficient crypt foci. (A) Resection sample with carcinoma in situ arising presumably from an MMR-deficient crypt. On the left panel, the overview of the resected sample (MLH1 staining); on the right upper panel, higher magnification of the MMR-deficient crypt (MLH1 staining); on the right lower panel, higher magnification of carcinoma in situ (MLH1 staining). (B) MLH1 staining revealing an MMR-deficient crypt (indicated by an arrow), on the left and another region of the same sample showing a non-invasive carcinoma in situ (indicated by arrows) on the right panel.

\subsection{Mutational Profile and MMR Deficiency Signatures in Incident Cancers}

We aimed to analyze how MMR deficiency influences mutational events in incident cancers and studied MMR deficiency signatures, namely the presence of $\mathrm{C}>\mathrm{T}$ transitions at CpG sites and insertion/deletion (indel) mutations in APC and KRAS mutations observed in incident cancers, and compared these to previous sequencing results obtained from prevalent CRC $[32,38,51]$.

In contrast to the relatively high prevalence of $K R A S$ codon $12 / 13$ mutations among prevalent LS CRCs described previously (11/21, 52\% [38]), only one codon 12 mutation was identified among the analyzed incident tumors $(1 / 23,4.3 \% ; p=0.0005)$ (Figure 3A,B, Supplementary Table S4). Moreover, no pathogenic TP53 mutations were identified in the analyzed set $(0 / 17)$, which compared to prevalent cancers $(7 / 21,33.3 \%$ [38]) yielded a significantly lower TP53 mutation frequency in incident CRCs ( $p=0.0108$, Figure 3A,B, Supplementary Table S4). KRAS and TP53 mutation frequencies remained significantly lower in incident compared to prevalent cancers $(1 / 19$ vs. $5 / 9, p=0.0066$ and $0 / 14$ vs. $4 / 9$ [38], $p=0.0142$, respectively) also when restricting the analysis to only $M L H 1$ carriers from both groups. The proportion of CTNNB1-mutant samples (5/23, 21.7\%) in incident cancers was similar to the proportion of CTNNB1-mutant tumors detected in prevalent cancers [51] $(10 / 48,20.8 \% ; p=1.0$, Figure 3A,B). Here, restricting the comparison to only MLH1 carriers yielded differing proportions (4/19, 21\% in incident cancer vs. $8 / 16,50 \%$ in prevalent cancer [51]), though not reaching statistical significance $(p=0.0896)$. 

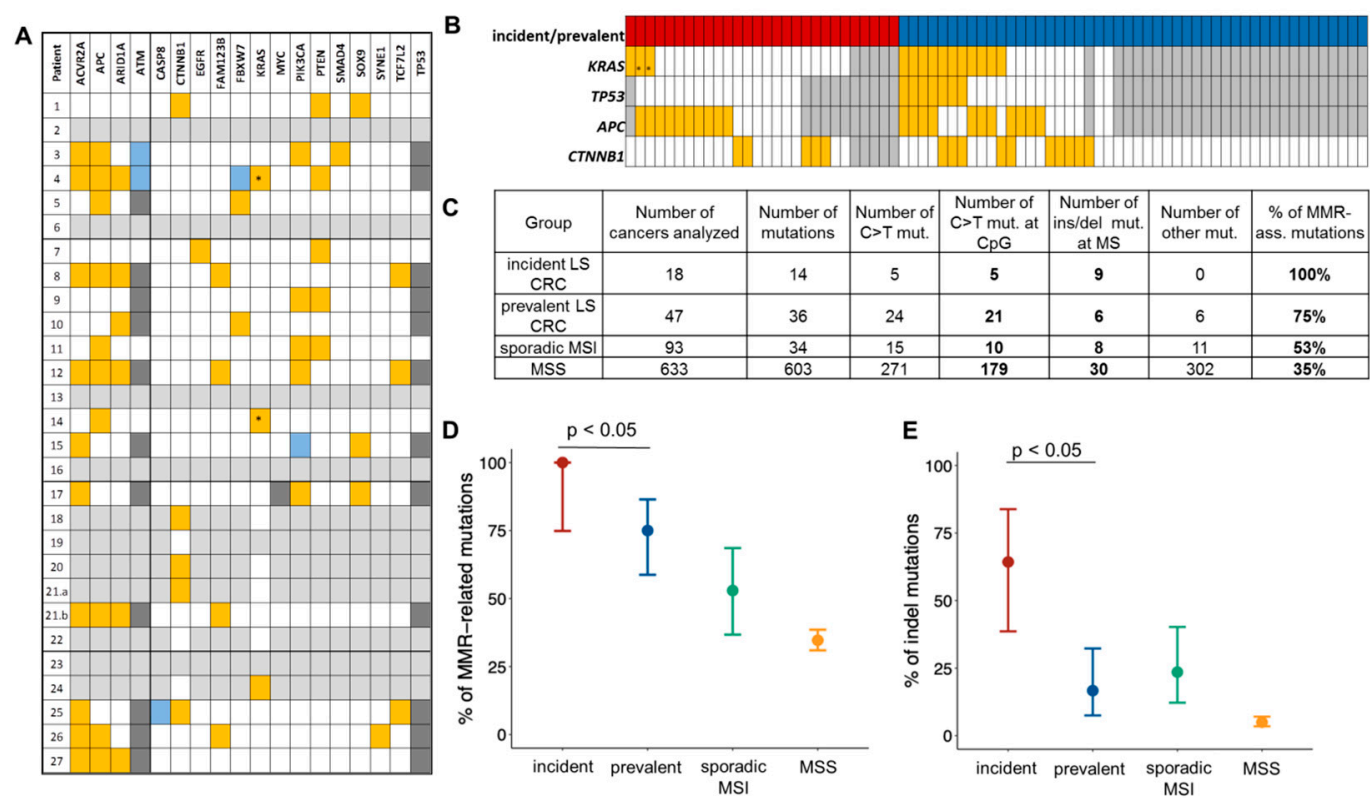

Figure 3. Mutational profile and MMR deficiency signatures in incident LS CRC. (A) Mutational characteristics of incident cancers (panel restricted to genes found mutant in at least one sample). Color code: orange-mutant, white-wild type, grey—n.a.; dark grey—known polymorphism, blue—variant of unknown significance; ${ }^{*}$-KRAS mutations at codons other than codon 12/13. (B) Mutation status of CRC genes in incident cancers analyzed in this study and prevalent cancers reported before [32,38] (for cohorts: red-incident CRC, blue-prevalent CRC, for genes-the same color code as in (A)). (C) Summary of the number of specific MMR deficiency-related mutations in incident LS CRC compared to prevalent LS CRC, sporadic MSI CRC and MSS CRC previously reported in Ahadova et al. [38]. (D) Comparison of the proportion of all MMR deficiency-related mutations between different CRC groups reveals a higher proportion in incident compared to prevalent tumors (100\%, 95\% CI: 74.85-100 vs. 75\%, 95\% CI: 58.7-86.4\%; Fisher's exact test, $p=0.0470)$. (E) Comparison of the proportion of indel mutations between different CRC groups reveals a higher proportion in incident compared to prevalent tumors $(64.3 \%$, 95\% CI: 38.6-83.8 vs. $16.7 \%$, 95\% CI: 7.5-32.3\%; Fisher's exact test, $p=0.0068)$.

Ten out of 17 incident cancers presented with a total of 14 truncating APC mutations (Figure 3B). All 14 detected APC mutations represented either $\mathrm{C}>\mathrm{T}$ transitions at $\mathrm{CpG}$ sites or insertion/deletion (indel) mutations, reflecting mutational signatures associated with MMR deficiency and arguing in favor of the early onset of MMR deficiency in LS incident CRC, prior to APC mutations. Importantly, the proportion of such mutations was significantly higher in incident cancers compared to prevalent cancers (100 vs. $75 \%$, 95\% CI: $74.9-100$ and 58.7-86.4\%, respectively; $p=0.0470$, Figure 3C,D).

When focusing on indel $A P C$ mutations alone, a significantly higher proportion of mutations was found in incident CRC compared to prevalent CRC in LS patients (64.3 vs. $16.7 \%$, 95\% CI: $38.6-83.8$ and 7.5-32.3\%, respectively; $p=0.0068$, Figure 3C,E).

\subsection{CMS Analysis in Incident Cancers}

Mutation frequencies obtained from the quantitative cMS analysis were compared between incident $(n=28)$ and prevalent $(n=67)$ tumors across all genes and for each gene. Generally, the frequency of cMS mutations in all 22 analyzed genes was slightly, but significantly elevated in the group of incident cancers compared to prevalent cancers (median 0.35 in incident vs. 0.31 in prevalent tumors, $p=0.018$, Figure 4A). Analysis restricted to only MLH1-associated cancers from both groups showed similarly high cMS mutation frequency between incident and prevalent cancers (median 0.34 in incident vs. 0.33 in prevalent tumors, $p=0.8721$, Supplementary Figure S2). As mutations at cMS presumably accumulate in association with the progression time of the tumor, we analyzed cMS mutation frequencies in association with the UICC stage. In prevalent LS CRC, we observed a significant increase in the cMS mutation frequencies from UICC I to UICC 
II (median for UICC I 0.28 vs. UICC II $0.36, p=0.002$, Figure $4 \mathrm{~B}$ ), whereas the incident LS CRC presented with high cMS mutation frequencies already in stage I tumors, and no further increase was observed in stage II tumors (Figure 4C). Importantly, the cMS mutation frequency was higher in stage I incident LS CRCs compared to stage I prevalent LS CRCs (median for UICC I in incident tumors 0.35 vs. 0.28 in prevalent tumors, $p=0.005$, Figure 4D).

A

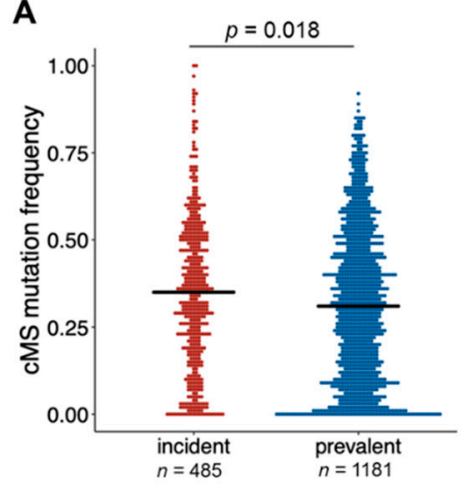

C

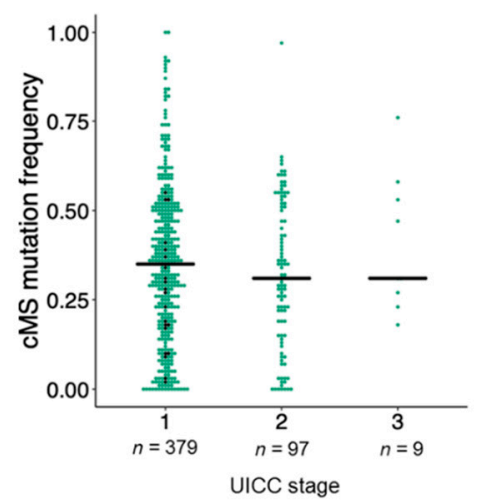

B

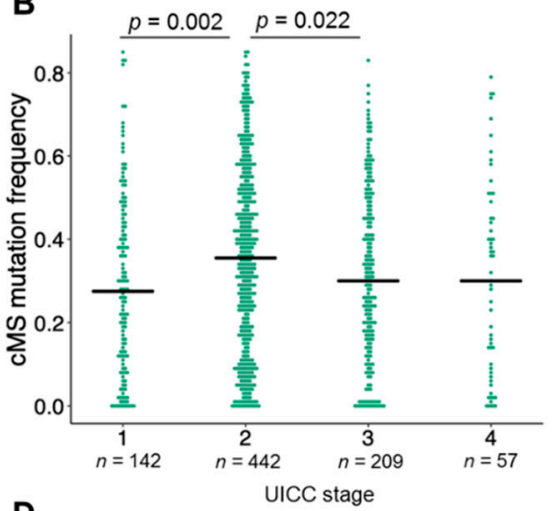

D

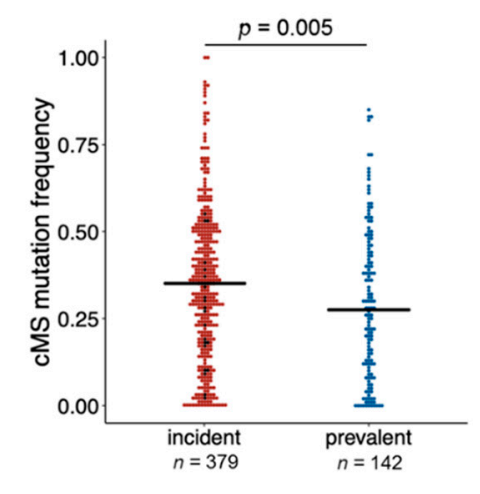

E
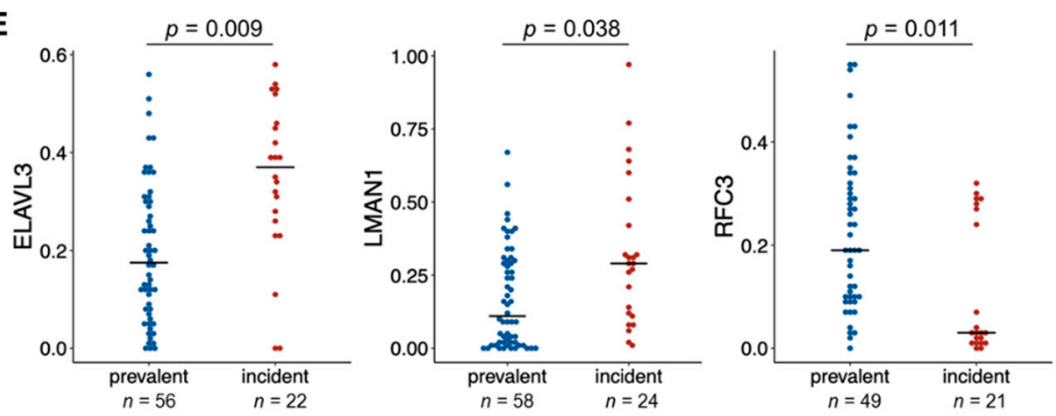

Figure 4. Analysis of coding microsatellite (cMS) mutations in incident and prevalent LS CRC. (A) cMS mutation frequency in incident and prevalent LS CRC. (B) cMS mutation frequency in prevalent LS CRC by UICC stage. (C) CMS mutation frequency in incident LS CRC by UICC stage (stage I group includes data from UICC 0 tumor, see black data points). (D) cMS mutation frequency in stage I incident (stage I group includes data from UICC 0 tumor, see black data points) and stage I prevalent LS CRC. (E) Individual CMS with significantly differing mutation rates between incident and prevalent cancers. Each dot represents one cMS locus in one tumor, and the $\mathrm{n}$ indicates the total number of analyzed cMS loci multiplied by the number of analyzable tumors. $p$ values were calculated using a two-sample Wilcoxon test (Mann-Whitney) and corrected for multiple testing using Benjamini-Hochberg procedure.

The analysis of mutations in 22 specific cMS genes revealed a significantly higher proportion of mutant alleles in two genes, LMAN1 (0.29 vs. $0.11, p=0.038)$ and ELAVL3 
( 0.37 vs. $0.17, p=0.009$ ), and a significantly lower proportion of mutant alleles in one of the analyzed cMS located in the RFC3 (0.03 vs. $0.19, p=0.011)$ gene in incident cancers compared to prevalent ones (Figure 4E, Supplementary Figure S3).

\subsection{Immune Infiltration and Immune Evasion in Incident Cancers}

We asked whether the early onset of MMR deficiency and the higher proportion of tumors with cMS mutations is reflected by the immune response in incident cancers, and analyzed the CD3-positive T cell infiltration in incident and prevalent LS CRC. As MMR gene-dependent differences in the immunogenicity of LS CRC have been reported before [51,52], we performed an MMR gene-wise comparison of immune infiltration, focusing on the MLH1-associated CRCs representing the vast majority in our incident cancer group (24/28). Dense immune infiltration was observed in both incident and prevalent tumor tissue (155 vs. $149 \mathrm{CD} 3+$ cells $/ 0.25 \mathrm{~mm}^{2}$, respectively) and normal mucosa, although no significant differences between incident and prevalent tumors could be detected ( $p=0.6$, Figure 5).

A

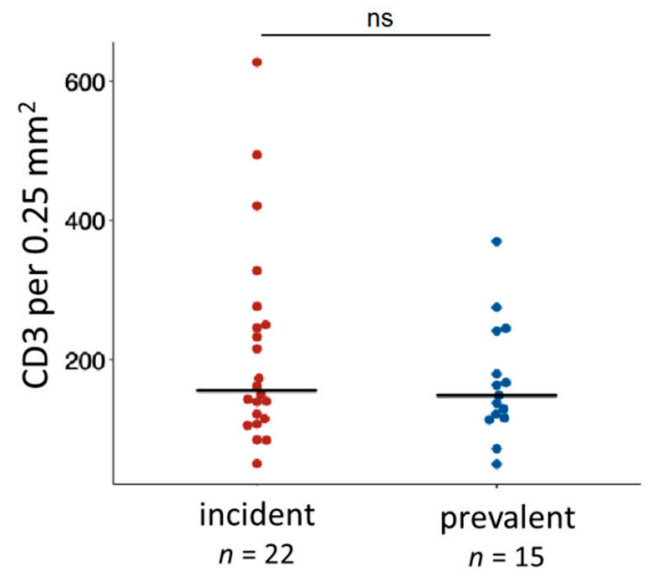

C

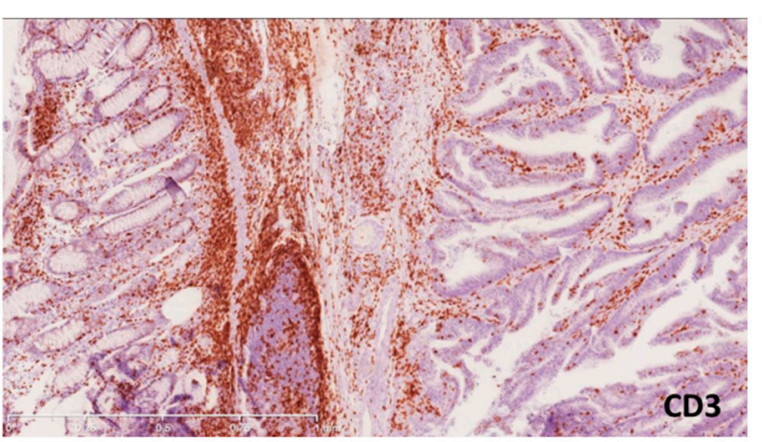

B

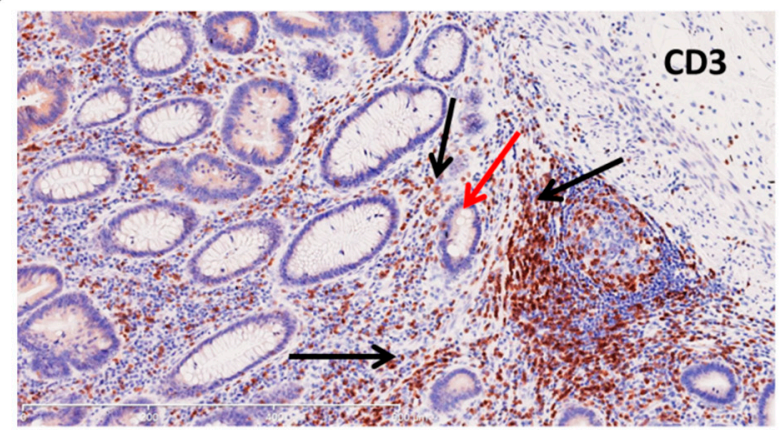

D

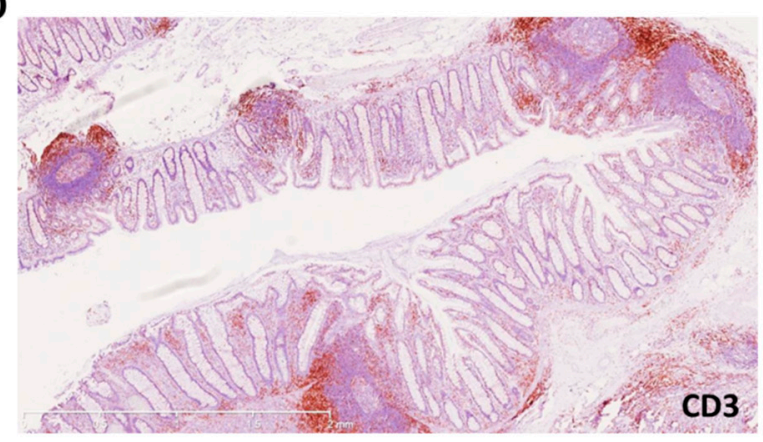

Figure 5. Immune infiltration with CD3-positive T cells in incident and prevalent cancers. (A) Immune infiltration in MLH1-associated incident and prevalent LS CRC. (B-D) Exemplary CD3 stainings of an MMR-deficient crypt (B) (see Figure 2B for the MLH1 staining, red arrow points to the MMR-deficient crypt, black arrows point at the CD3-positive T cell infiltration), tumor (C) and normal mucosa (D) regions of a transverse colon cancer specimen.

The pronounced immune response against MSI CRC often results in the acquisition of $B 2 M$ mutations, the most common mechanism of immune evasion in MSI tumors leading to abrogation of HLA class I-mediated antigen presentation $[48,53]$. We analyzed $B 2 M$ in incident and prevalent CRCs and found a B2M mutation prevalence of $20.8 \%(5 / 24)$ in incident CRC, which was similar to the B2M mutation prevalence of prevalent CRC $(13 / 54$, $24.1 \% ; p=1.0)$. 


\section{Discussion}

In the present study, we provide first evidence that incident CRCs in LS are distinct from prevalent cancers with regard to their clinical, histological and mutational characteristics.

Clinically, most incident cancers were of UICC stage I/II and thus of significantly lower stage than the prevalent cancers of our control cohort. Low tumor stage, typical absence of lymph node involvement and a favorable clinical course of incident cancers observed in our study are in line with previous reports $[11,18,22,36,54,55]$. Only one CRCrelated death was clearly associated with a primary CRC included in this study and showed signet ring cell features, associated with poor survival [56]. This mirrors the previously reported excellent survival under prospective observation [57], which could be attributed to the early detection via colonoscopy.

Histologically, tumors with mucinous components were frequent among incident CRCs in LS (57.1 vs. $35.1 \%$ in prevalent cancers). Presentation with mucinous histology in MSI cancer has previously been associated with a high cMS mutational load [58]. The elevated cMS mutation frequency detected in incident cancers of our study (Figure 4) may therefore be responsible for a high mutational variability resulting in mixed and mucinous histology. Interestingly, tumors with non-polypoid, depressed growth pattern were not substantially enriched among incident cancers compared to prevalent ones. This, together with the rather low prevalence of CTNNB1 mutations among MLH1-associated incident cancers, could indicate that the progression with immediate invasive growth was not dominant in the analyzed set of incident cancers.

Two hypotheses might explain the observed differences: first, incident cancers may in fact predominantly develop via a distinct, MMR deficiency-initiated CRC evolution. Alternatively, incident and prevalent cancers could be two entities representing manifestations of the same evolutionary pathway, detected at different time points.

The hypothesis of incident cancers representing a distinct, MMR deficiency-initiated group of tumors is compatible with two additional observations: (1) Histologically normal MMR-deficient crypt foci were detected in the direct vicinity of two incident tumors, providing indirect evidence that MMR-deficient crypts may give rise to CRC development in LS. Clonality studies of LS tumors and adjacent MMR-deficient crypts are required to provide direct proof of such associations; (2) On the molecular level, APC mutations in incident CRCs showed a significantly stronger association with signatures of MMR deficiency [59] than in prevalent CRCs, indicating that MMR deficiency as an early event commonly precedes APC mutations.

Importantly, we found significantly less KRAS mutations in incident cancers than previous studies analyzing prevalent CRC in LS [60]. Two scenarios for the observations are possible: (1) Colonoscopy with adenoma removal may theoretically be more effective in preventing KRAS-mutated lesions, as KRAS mutations are associated with conventional adenomas $[61,62]$. This would imply that incident cancers may develop from other, KRAS wild-type lesions that are more difficult to detect. In fact, a recent study analyzing the efficacy of colonoscopy depending on the molecular subtype of tumors in the general population showed a weaker CRC risk reduction after colonoscopy for KRAS wild-type tumors [63]; (2) Alternatively, oncogene-activating missense mutations, which need to affect very specific nucleotides and therefore have a lower likelihood per genome replication than indel mutations, may be less frequent in tumors with rapid evolution and short progression times such as incident cancers [64]. This hypothesis could also explain the absence of TP53 point mutations, which are generally considered late events in colorectal carcinogenesis [65], and the relative scarcity of CTNNB1-activating point mutations in the incident CRC of our study, which were mostly of low stage. Notably, the only codon 12 KRAS mutation in incident CRCs was detected in a stage I tumor.

CTNNB1 mutation frequency in incident cancers is particularly low when restricting the comparison to MLH1-associated LS cancers. Somatic CTNNB1 mutations have been previously associated with $M L H 1$ germline variants, and a rather low prevalence of CTNNB1-mutant tumors among MLH1-associated incident cancers compared to their 
reported frequency in MLH1-associated prevalent cancers is unexpected and could point at different routes of progression between $M L H 1$-associated incident and prevalent cancers. In addition, as somatic MLH1 and CTNNB1 mutations seem to be non-independent events [66], large deletions of the MLH1 gene prevailing in the Finnish population as a founder variant may have an impact on the routes of cancer progression and the likelihood of somatic CTNNB1 mutations [67]. The mechanistic reasons behind the association between $M L H 1$ germline variants and CTNNB1 somatic mutations remain to be clarified by future studies.

Conceptually, the significantly lower prevalence of KRAS and TP53 mutations in incident cancers could reflect earlier sampling, assuming that these mutations represent late events in CRC evolution. Following this interpretation of incident cancers and prevalent cancers as manifestations of one and the same linear evolutionary continuum, one would expect that the amount of cMS mutations is higher in prevalent (i.e., late) than in incident (i.e., early) cancers. However, the cMS mutation load of incident CRCs in our study was always in the same range or even higher in subgroups or overall comparisons compared to prevalent CRC. Notably, significantly elevated cMS mutation frequencies were observed for incident compared to prevalent cancers of UICC stage I, although this observation needs confirmation, because the number of such cancers was small in the prevalent cancer group. This observation is not in line with the suggestion that incident and prevalent cancers represent two different time points in the same CRC progression pathway. Interestingly, despite observing clearly higher cMS mutation frequencies in stage II vs. stage I prevalent cancer, for stage III and IV no further increase in cMS mutation frequencies was observed. Limited sample size or saturation effect could be possible explanations for this observation. In addition, one may speculate that cell clones with high cMS loads and consequently also high antigen load could undergo negative selection upon tumor immunoediting, favoring outgrowth of tumor cell clones with lower cMS loads. The elimination of highly immunogenic cell clones by the immune system during MSI carcinogenesis has been previously suggested [45]. However, the link between tumor immunoediting and lower cMS mutations frequencies at higher tumor stages remains to be clarified by other studies.

We are aware that our observation of cMS mutation frequency is based on targeted analysis of a limited set of 28 common mutational targets in MSI CRC [45]. In the future, NGS-based genome-wide analyses, which have limited applicability for mutation calling of cMS, such as TGFBR2 in individual tumors $[45,68]$, but are superior in detecting general, genome-wide effects, are warranted to quantitatively confirm cMS mutation loads in incident CRC.

By applying the ReFrame algorithm as a highly sensitive method to detect and quantify specific cMS mutations [45], we were able to detect significant differences in mutation frequency for three individual cMS between incident and prevalent cancers: two cMS genes, LMAN1 and ELAVL3, showed significantly higher mutation frequencies in incident compared to prevalent cancers, whereas the RFC3 cMS gene showed a significantly lower mutation frequency, thereby notably showing changes in mutation frequencies in both directions. Functionally, LMAN1 is a lectin transporting glycoproteins from the endoplasmic reticulum to the Golgi apparatus [69], RFC3 is a protein participating in DNA proliferation [70], whereas the function of ELAVL3 is less well studied. LMAN1 cMS mutations have been previously detected in hereditary MSI adenomas and suggested to play a role in early MSI-driven carcinogenesis [69], which could explain their high frequency in incident cancers. ELAVL3 and RFC3 cMS genes are well conserved between humans and mice and have been shown to be mutated in extracolonic MSI tumor types [43,71]. Though the exact role of these cMS mutations in incident cancer development remains elusive and the results will require confirmation in independent tumor collections, these observations point towards biological differences between incident and prevalent cancers and thus add further support to the hypothesis of two distinct entities.

Colonoscopy quality might be another factor responsible for the development of cancers under surveillance. In our study, colonoscopies performed prior to the examination 
revealing cancer with the endoscopy equipment available at the recruitment period (before the introduction of high-definition endoscopy) were documented as complete procedures fulfilling the criteria for a high-quality colonoscopy (evidence of full visualization of the remaining bowel length and adequate bowel preparation) [72]. This is in line with the previous observations by Lappalainen et al., showing no association between incident cancers and a prior colonoscopy of compromised quality [73]. Additionally, the proportion of tumors located in the proximal colon, a localization often associated with lower colonoscopy sensitivity $[15,63]$, was identical between incident and prevalent tumors analyzed in our study, indicating that localization-related colonoscopy sensitivity alone also does not explain the occurrence of incident CRCs in LS carriers under surveillance. The adenoma detection rate (ADR) in the contributing centers for follow-up colonoscopies has also been shown to be comparable with the previous reports of recent large prospective studies [22,73]. However, as there is a certain time trend towards higher ADR after the introduction of high-definition endoscopes, it cannot be ruled out that at least a proportion of incident cancers included in this study could have been prevented if currently available technical equipment was used. It seems reasonable to assume that screening parameters such as ADR and colonoscopy interval have a significant impact on the appearance and characteristics of interval cancers. The observed correlation of the growth pattern of incident cancers with time since last colonoscopy could point at a longer dwell time of tumors with polypoid growth pattern compared to tumors with depressed growth pattern. Taking into account the limited number of samples available for this analysis, this observation needs confirmation by future larger studies, ideally also including the endoscopic images of the lesions identified during colonoscopy examinations.

In line with previous observations reported by the Prospective Lynch Syndrome Database (PLSD) [54] and other large studies [22,36], no correlation was observed between time since last colonoscopy and tumor stage among incident cancers. Previous studies reported incident cancer development in the same segment of colon, where previously a polypectomy was performed, in $20-50 \%$ of cases [36,74]. Although no information on the localization of a lesion detected at previous colonoscopy was available in this study, adenoma at previous colonoscopy was found in $25 \%$ of patients with incident cancers, which is in line with other reports $[18,36,73]$.

The strength of our study is the first molecular characterization of incident cancers in LS and their comparison to prevalent CRC in LS, as well as high-resolution analysis of MMR deficiency-associated mutational events using a newly established method [45]. The weakness of the study is the analysis of incident cancers from a single country with a clinical practice of 3-year colonoscopy intervals. As no structural differences have been observed in patients from different countries in previous studies with regard to their tumor risk [51], we do not expect a major influence of the sample source on our data. Moreover, all tumors were diagnosed after an interval of 40 months or less (median 27 months), with $25 \%$ of tumors after an interval of 2 years or less from previous colonoscopy. The proportion of tumors diagnosed due to symptoms was higher among prevalent compared to incident cancer groups, and a comparison with prevalent cancers detected in patients diagnosed with LS as a result of cascade testing may deliver clearer insights into differences between incident and prevalent cancer. Another limitation of our study is that the majority of incident cancers were from patients harboring MLH1 germline variants, and thereby represented only one of the two $M M R$ genes most frequently associated with incident cancer [51]. Validation of our results in a larger international multi-center study is therefore warranted in order to include more $\mathrm{MSH} 2$ pathogenic variant carriers to analyze and examine potential differences between MLH1 and MSH2-associated LS, as has been suggested recently [51]. Ideally, a standardized, prospectively collected cohort of incident and prevalent CRCs allowing for a gene- and stage-matched comparison would be required to validate our results. 


\section{Conclusions}

In conclusion, our study for the first time identifies a set of features indicative of biological differences between incident and prevalent cancers in LS: a lower tumor stage, a high proportion of tumors with mucinous areas, a predominance of indel mutations over point mutations and a low prevalence of $R A S$ mutations. These features should further be monitored in prospective LS screening studies to guide towards optimized prevention protocols, including all available options of high-quality colonoscopy and primary prevention approaches.

Supplementary Materials: The following are available online at https:/ /www.mdpi.com/article/ 10.3390/jcm10112458/s1. Figure S1: Correlation analysis between time since last colonoscopy (in months) and the stage of detected tumor among incident CRCs; Figure S2: CMS mutation frequencies in MLH1-associated incident and prevalent cancers; Figure S3: Heat map of the relative frequency of mutant alleles is shown for $22 \mathrm{cMS}$ (columns) in incident (rows marked red on the left side) and prevalent (rows marked blue on the left side) CRC obtained using ReFrame; Table S1: Primer sequences; Table S2: Histopathological characteristics of incident cancers; Table S3: Histopathological characteristics of prevalent cancers; Table S4: Summary of the mutation status in key CRC genes.

Author Contributions: Conceptualization, A.A., J.-P.M., T.T.S. and M.K.; Data curation, A.A., P.L.P., M.A., A.B., L.B. and T.T.S.; Formal analysis, A.A., P.L.P., M.A., A.B., L.B., S.K., N.M., Y.L.T., K.K., J.W., V.E., A.S., L.R.-S., A.L., J.B. and T.T.S.; Funding acquisition, M.v.K.D., H.B., J.-P.M., T.T.S. and M.K.; Investigation, A.A., P.L.P., M.A., A.B., L.B., S.K., N.M., Y.L.T., K.K., J.W., V.E., A.S., L.R.-S., A.L., J.B. and T.T.S.; Methodology, A.A., J.-P.M., T.T.S. and M.K.; Project administration, T.T.S. and M.K.; Supervision, M.v.K.D., J.-P.M., T.T.S. and M.K.; Validation, A.A., P.L.P., T.T.S. and M.K.; Visualization, A.A. and P.L.P.; Writing-original draft, A.A., P.L.P., Y.L.T., J.-P.M., T.T.S., and M.K.; Writing-review and editing, A.A., P.L.P., M.A., A.B., L.B., S.K., N.M., Y.L.T., K.K., J.W., V.E., A.S., M.v.K.D., H.B., L.R.-S., A.L., J.B., J.-P.M., T.T.S. and M.K. All authors have read and agreed to the published version of the manuscript.

Funding: This research was funded by the Wilhelm Sander Foundation (grant number 2016.056.1), Emil Aaltonen Foundation, Finnish Medical Foundation, Sigrid Juselius Foundation, Finnish State Research Funds (VTR), the Finnish Cancer Foundation and Jane and Aatos Erkko Foundation. The funders had no role in study design, data collection and analysis, decision to publish or preparation of the manuscript.

Institutional Review Board Statement: The study was conducted according to the guidelines of the Declaration of Helsinki, and approved by the Institutional Ethics Committee of the University Hospital Heidelberg and Central Finland Hospital District Ethical Committee.

Informed Consent Statement: Informed consent was obtained from all subjects involved in the study.

Data Availability Statement: All data presented in the manuscript are available at the Department of Applied Tumor Biology, University Hospital Heidelberg and can be shared upon request.

Acknowledgments: The excellent technical support of Nina Nelius, Petra Höfler and Lena EhretMaßholder is gratefully acknowledged.

Conflicts of Interest: The authors declare no conflict of interest.

\section{References}

1. Jasperson, K.W.; Tuohy, T.M.; Neklason, D.W.; Burt, R.W. Hereditary and familial colon cancer. Gastroenterology 2010, 138, 2044-2058. [CrossRef] [PubMed]

2. De la Chapelle, A. Microsatellite instability. N. Engl. J. Med. 2003, 349, 209-210. [CrossRef]

3. Woerner, S.M.; Kloor, M.; von Knebel Doeberitz, M.; Gebert, J.F. Microsatellite instability in the development of DNA mismatch repair deficient tumors. Cancer Biomark. Sect. A Dis. Mark. 2006, 2, 69-86. [CrossRef]

4. Linnebacher, M.; Gebert, J.; Rudy, W.; Woerner, S.; Yuan, Y.P.; Bork, P.; von Knebel Doeberitz, M. Frameshift peptide-derived T-cell epitopes: A source of novel tumor-specific antigens. Int. J. Cancer 2001, 93, 6-11. [CrossRef]

5. Buckowitz, A.; Knaebel, H.P.; Benner, A.; Blaker, H.; Gebert, J.; Kienle, P.; von Knebel Doeberitz, M.; Kloor, M. Microsatellite instability in colorectal cancer is associated with local lymphocyte infiltration and low frequency of distant metastases. Brit. J. Cancer 2005, 92, 1746-1753. [CrossRef] 
6. Popat, S.; Hubner, R.; Houlston, R.S. Systematic review of microsatellite instability and colorectal cancer prognosis. J. Clin. Oncol. 2005, 23, 609-618. [CrossRef]

7. Le, D.T.; Uram, J.N.; Wang, H.; Bartlett, B.R.; Kemberling, H.; Eyring, A.D.; Skora, A.D.; Luber, B.S.; Azad, N.S.; Laheru, D.; et al. PD-1 Blockade in Tumors with Mismatch-Repair Deficiency. N. Engl. J. Med. 2015, 372, 2509-2520. [CrossRef] [PubMed]

8. Le, D.T.; Durham, J.N.; Smith, K.N.; Wang, H.; Bartlett, B.R.; Aulakh, L.K.; Lu, S.; Kemberling, H.; Wilt, C.; Luber, B.S.; et al. Mismatch repair deficiency predicts response of solid tumors to PD-1 blockade. Science 2017, 357, 409-413. [CrossRef]

9. Vasen, H.F.; Blanco, I.; Aktan-Collan, K.; Gopie, J.P.; Alonso, A.; Aretz, S.; Bernstein, I.; Bertario, L.; Burn, J.; Capella, G.; et al. Revised guidelines for the clinical management of Lynch syndrome (HNPCC): Recommendations by a group of European experts. Gut 2013, 62, 812-823. [CrossRef] [PubMed]

10. Stormorken, A.T.; Clark, N.; Grindedal, E.; Maehle, L.; Moller, P. Prevention of colorectal cancer by colonoscopic surveillance in families with hereditary colorectal cancer. Scand. J. Gastroenterol. 2007, 42, 611-617. [CrossRef] [PubMed]

11. Jarvinen, H.J.; Aarnio, M.; Mustonen, H.; Aktan-Collan, K.; Aaltonen, L.A.; Peltomaki, P.; De La Chapelle, A.; Mecklin, J.P. Controlled 15-year trial on screening for colorectal cancer in families with hereditary nonpolyposis colorectal cancer. Gastroenterology 2000, 118, 829-834. [CrossRef]

12. Newton, K.; Green, K.; Lalloo, F.; Evans, D.G.; Hill, J. Colonoscopy screening compliance and outcomes in patients with Lynch syndrome. Colorect. Dis. Off. J. Assoc. Coloproctol. G. B. Irel. 2015, 17, 38-46. [CrossRef]

13. Jarvinen, H.J.; Renkonen-Sinisalo, L.; Aktan-Collan, K.; Peltomaki, P.; Aaltonen, L.A.; Mecklin, J.P. Ten years after mutation testing for Lynch syndrome: Cancer incidence and outcome in mutation-positive and mutation-negative family members. J. Clin. Oncol. 2009, 27, 4793-4797. [CrossRef]

14. Renkonen-Sinisalo, L.; Aarnio, M.; Mecklin, J.P.; Jarvinen, H.J. Surveillance improves survival of colorectal cancer in patients with hereditary nonpolyposis colorectal cancer. Cancer Detect. Prevent. 2000, 24, 137-142.

15. Brenner, H.; Chang-Claude, J.; Jansen, L.; Knebel, P.; Stock, C.; Hoffmeister, M. Reduced risk of colorectal cancer up to 10 years after screening, surveillance, or diagnostic colonoscopy. Gastroenterology 2014, 146, 709-717. [CrossRef]

16. Brenner, H.; Chang-Claude, J.; Seiler, C.M.; Rickert, A.; Hoffmeister, M. Protection from colorectal cancer after colonoscopy: A population-based, case-control study. Ann. Intern. Med. 2011, 154, 22-30. [CrossRef]

17. Samadder, N.J.; Curtin, K.; Pappas, L.; Boucher, K.; Mineau, G.P.; Smith, K.; Fraser, A.; Wan, Y.; Provenzale, D.; Kinney, A.Y.; et al. Risk of Incident Colorectal Cancer and Death After Colonoscopy: A Population-based Study in Utah. Clin. Gastroenterol. Hepatol. 2016, 14, 279-286.e2. [CrossRef] [PubMed]

18. Engel, C.; Rahner, N.; Schulmann, K.; Holinski-Feder, E.; Goecke, T.O.; Schackert, H.K.; Kloor, M.; Steinke, V.; Vogelsang, H.; Moslein, G.; et al. Efficacy of annual colonoscopic surveillance in individuals with hereditary nonpolyposis colorectal cancer. Clin. Gastroenterol. Hepatol. 2010, 8, 174-182. [CrossRef] [PubMed]

19. De Vos tot Nederveen Cappel, W.H.; Nagengast, F.M.; Griffioen, G.; Menko, F.H.; Taal, B.G.; Kleibeuker, J.H.; Vasen, H.F. Surveillance for hereditary nonpolyposis colorectal cancer: A long-term study on 114 families. Dis. Colon Rectum 2002, 45, 1588-1594. [CrossRef] [PubMed]

20. Vasen, H.F.; Moslein, G.; Alonso, A.; Bernstein, I.; Bertario, L.; Blanco, I.; Burn, J.; Capella, G.; Engel, C.; Frayling, I.; et al. Guidelines for the clinical management of Lynch syndrome (hereditary non-polyposis cancer). J. Med. Genet. 2007, 44, 353-362. [CrossRef] [PubMed]

21. Mecklin, J.P.; Aarnio, M.; Laara, E.; Kairaluoma, M.V.; Pylvanainen, K.; Peltomaki, P.; Aaltonen, L.A.; Jarvinen, H.J. Development of colorectal tumors in colonoscopic surveillance in Lynch syndrome. Gastroenterology 2007, 133, 1093-1098. [CrossRef]

22. Engel, C.; Vasen, H.F.; Seppala, T.; Aretz, S.; Bigirwamungu-Bargeman, M.; de Boer, S.Y.; Bucksch, K.; Buttner, R.; Holinski-Feder, E.; Holzapfel, S.; et al. No Difference in Colorectal Cancer Incidence or Stage at Detection by Colonoscopy Among 3 Countries with Different Lynch Syndrome Surveillance Policies. Gastroenterology 2018, 155, 1400-1409. [CrossRef]

23. Moller, P.; Seppala, T.; Bernstein, I.; Holinski-Feder, E.; Sala, P.; Evans, D.G.; Lindblom, A.; Macrae, F.; Blanco, I.; Sijmons, R.; et al. Cancer incidence and survival in Lynch syndrome patients receiving colonoscopic and gynaecological surveillance: First report from the prospective Lynch syndrome database. Gut 2017, 66, 464-472. [CrossRef]

24. Rutter, M.D.; Beintaris, I.; Valori, R.; Chiu, H.M.; Corley, D.A.; Cuatrecasas, M.; Dekker, E.; Forsberg, A.; Gore-Booth, J.; Haug, U.; et al. World Endoscopy Organization Consensus Statements on Post-Colonoscopy and Post-Imaging Colorectal Cancer. Gastroenterology 2018, 155, 909-925. [CrossRef] [PubMed]

25. Moller, P.; Seppala, T.T.; Bernstein, I.; Holinski-Feder, E.; Sala, P.; Gareth Evans, D.; Lindblom, A.; Macrae, F.; Blanco, I.; Sijmons, R.H.; et al. Cancer risk and survival in path_MMR carriers by gene and gender up to 75 years of age: A report from the Prospective Lynch Syndrome Database. Gut 2018, 67, 1306-1316. [CrossRef] [PubMed]

26. Bonadona, V.; Bonaiti, B.; Olschwang, S.; Grandjouan, S.; Huiart, L.; Longy, M.; Guimbaud, R.; Buecher, B.; Bignon, Y.J.; Caron, O.; et al. Cancer risks associated with germline mutations in MLH1, MSH2, and MSH6 genes in Lynch syndrome. JAMA 2011, 305, 2304-2310. [CrossRef] [PubMed]

27. Dowty, J.G.; Win, A.K.; Buchanan, D.D.; Lindor, N.M.; Macrae, F.A.; Clendenning, M.; Antill, Y.C.; Thibodeau, S.N.; Casey, G.; Gallinger, S.; et al. Cancer risks for MLH1 and MSH2 mutation carriers. Hum. Mutat. 2013, 34, 490-497. [CrossRef] [PubMed]

28. Ten Broeke, S.W.; van der Klift, H.M.; Tops, C.M.J.; Aretz, S.; Bernstein, I.; Buchanan, D.D.; de la Chapelle, A.; Capella, G.; Clendenning, M.; Engel, C.; et al. Cancer Risks for PMS2-Associated Lynch Syndrome. J. Clin. Oncol. 2018, 36, 2961-2968. [CrossRef] [PubMed] 
29. Ahadova, A.; Seppala, T.T.; Engel, C.; Gallon, R.; Burn, J.; Holinski-Feder, E.; Steinke-Lange, V.; Moslein, G.; Nielsen, M.; Ten Broeke, S.W.; et al. The "unnatural" history of colorectal cancer in Lynch syndrome: Lessons from colonoscopy surveillance. Int. J. Cancer 2021, 148, 800-811. [CrossRef] [PubMed]

30. Latchford, A. How Should Colonoscopy Surveillance in Lynch Syndrome Be Performed? Gastroenterology 2020, 158, 818-819. [CrossRef]

31. Sawhney, M.S.; Farrar, W.D.; Gudiseva, S.; Nelson, D.B.; Lederle, F.A.; Rector, T.S.; Bond, J.H. Microsatellite instability in interval colon cancers. Gastroenterology 2006, 131, 1700-1705. [CrossRef] [PubMed]

32. Ahadova, A.; von Knebel Doeberitz, M.; Blaker, H.; Kloor, M. CTNNB1-mutant colorectal carcinomas with immediate invasive growth: A model of interval cancers in Lynch syndrome. Fam. Cancer 2016, 15, 579-586. [CrossRef] [PubMed]

33. Kloor, M.; Huth, C.; Voigt, A.Y.; Benner, A.; Schirmacher, P.; von Knebel Doeberitz, M.; Blaker, H. Prevalence of mismatch repair-deficient crypt foci in Lynch syndrome: A pathological study. Lancet Oncol. 2012, 13, 598-606. [CrossRef]

34. Staffa, L.; Echterdiek, F.; Nelius, N.; Benner, A.; Werft, W.; Lahrmann, B.; Grabe, N.; Schneider, M.; Tariverdian, M.; von Knebel Doeberitz, M.; et al. Mismatch repair-deficient crypt foci in Lynch syndrome-Molecular alterations and association with clinical parameters. PLOS ONE 2015, 10, e0121980. [CrossRef]

35. Pai, R.K.; Dudley, B.; Karloski, E.; Brand, R.E.; O'Callaghan, N.; Rosty, C.; Buchanan, D.D.; Jenkins, M.A.; Thibodeau, S.N.; French, A.J.; et al. DNA mismatch repair protein deficient non-neoplastic colonic crypts: A novel indicator of Lynch syndrome. Mod. Pathol. 2018, 31, 1608-1618. [CrossRef]

36. Argillander, T.E.; Koornstra, J.J.; van Kouwen, M.; Langers, A.M.; Nagengast, F.M.; Vecht, J.; de Vos Tot Nederveen Cappel, W.H.; Dekker, E.; van Duijvendijk, P.; Vasen, H.F. Features of incident colorectal cancer in Lynch syndrome. United Eur. Gastroenterol. J. 2018, 6, 1215-1222. [CrossRef]

37. Lambert, R. The Paris endoscopic classification of superficial neoplastic lesions: Esophagus, stomach, and colon: November 30 to December 1, 2002. Gastrointest. Endosc. 2003, 58, S3-S43. [CrossRef]

38. Ahadova, A.; Gallon, R.; Gebert, J.; Ballhausen, A.; Endris, V.; Kirchner, M.; Stenzinger, A.; Burn, J.; von Knebel Doeberitz, M.; Blaker, H.; et al. Three molecular pathways model colorectal carcinogenesis in Lynch syndrome. Int. J. Cancer 2018, 143, 139-150. [CrossRef]

39. Jesinghaus, M.; Pfarr, N.; Endris, V.; Kloor, M.; Volckmar, A.L.; Brandt, R.; Herpel, E.; Muckenhuber, A.; Lasitschka, F.; Schirmacher, P.; et al. Genotyping of colorectal cancer for cancer precision medicine: Results from the IPH Center for Molecular Pathology. Genes Chromosom. Cancer 2016, 55, 505-521. [CrossRef] [PubMed]

40. Wang, K.; Li, M.; Hakonarson, H. ANNOVAR: Functional annotation of genetic variants from high-throughput sequencing data. Nucleic Acids Res. 2010, 38, e164. [CrossRef] [PubMed]

41. Robinson, J.T.; Thorvaldsdottir, H.; Winckler, W.; Guttman, M.; Lander, E.S.; Getz, G.; Mesirov, J.P. Integrative genomics viewer. Nat. Biotechnol. 2011, 29, 24-26. [CrossRef]

42. Findeisen, P.; Kloor, M.; Merx, S.; Sutter, C.; Woerner, S.M.; Dostmann, N.; Benner, A.; Dondog, B.; Pawlita, M.; Dippold, W.; et al. T25 repeat in the $3^{\prime}$ untranslated region of the CASP2 gene: A sensitive and specific marker for microsatellite instability in colorectal cancer. Cancer Res. 2005, 65, 8072-8078. [CrossRef] [PubMed]

43. Woerner, S.M.; Yuan, Y.P.; Benner, A.; Korff, S.; von Knebel Doeberitz, M.; Bork, P. SelTarbase, a database of human mononucleotide-microsatellite mutations and their potential impact to tumorigenesis and immunology. Nucleic Acids Res. 2010, 38, D682-D689. [CrossRef] [PubMed]

44. Jurtz, V.; Paul, S.; Andreatta, M.; Marcatili, P.; Peters, B.; Nielsen, M. NetMHCpan-4.0: Improved Peptide-MHC Class I Interaction Predictions Integrating Eluted Ligand and Peptide Binding Affinity Data. J. Immunol. 2017, 199, 3360-3368. [CrossRef]

45. Ballhausen, A.; Przybilla, M.J.; Jendrusch, M.; Haupt, S.; Pfaffendorf, E.; Seidler, F.; Witt, J.; Hernandez Sanchez, A.; Urban, K.; Draxlbauer, M.; et al. The shared frameshift mutation landscape of microsatellite-unstable cancers suggests immunoediting during tumor evolution. Nat. Commun. 2020, 11, 4740. [CrossRef] [PubMed]

46. Pfuderer, P.L.; Ballhausen, A.; Seidler, F.; Stark, H.J.; Grabe, N.; Frayling, I.M.; Ager, A.; von Knebel Doeberitz, M.; Kloor, M.; Ahadova, A. High endothelial venules are associated with microsatellite instability, hereditary background and immune evasion in colorectal cancer. Brit. J. Cancer 2019, 121, 395-404. [CrossRef]

47. Kloor, M.; Sutter, C.; Wentzensen, N.; Cremer, F.W.; Buckowitz, A.; Keller, M.; von Knebel Doeberitz, M.; Gebert, J. A large MSH2 Alu insertion mutation causes HNPCC in a German kindred. Hum. Genet. 2004, 115, 432-438. [CrossRef] [PubMed]

48. Janikovits, J.; Muller, M.; Krzykalla, J.; Korner, S.; Echterdiek, F.; Lahrmann, B.; Grabe, N.; Schneider, M.; Benner, A.; Doeberitz, M.V.K.; et al. High numbers of PDCD1 (PD-1)-positive T cells and B2M mutations in microsatellite-unstable colorectal cancer. Oncoimmunology 2018, 7, e1390640. [CrossRef]

49. Team, R.C. R: A Language and Environment for Statistical Computing; R Version 3.6.0.R; R Foundation for Statistical Computing: Vienna, Austria, 2019.

50. Team, R. RStudio: Integrated Development for R; RStudio: Boston, MA, USA, 2018.

51. Engel, C.; Ahadova, A.; Seppala, T.; Aretz, S.; Bigirwamungu-Bargeman, M.; Blaker, H.; Bucksch, K.; Buttner, R.; de Vos Tot Nederveen Cappel, W.; Endris, V.; et al. Associations of Pathogenic Variants in MLH1, MSH2, and MSH6 with Risk of Colorectal Adenomas and Tumors and with Somatic Mutations in Patients with Lynch Syndrome. Gastroenterology 2020. [CrossRef] 
52. Binder, H.; Hopp, L.; Schweiger, M.R.; Hoffmann, S.; Juhling, F.; Kerick, M.; Timmermann, B.; Siebert, S.; Grimm, C.; Nersisyan, L.; et al. Genomic and transcriptomic heterogeneity of colorectal tumours arising in Lynch syndrome. J. Pathol. 2017, 243, 242-254. [CrossRef]

53. Kloor, M.; Michel, S.; Buckowitz, B.; Ruschoff, J.; Buttner, R.; Holinski-Feder, E.; Dippold, W.; Wagner, R.; Tariverdian, M.; Benner, A.; et al. Beta2-microglobulin mutations in microsatellite unstable colorectal tumors. Int. J. Cancer 2007, 121, 454-458. [CrossRef] [PubMed]

54. Seppala, T.T.; Ahadova, A.; Dominguez-Valentin, M.; Macrae, F.; Evans, D.G.; Therkildsen, C.; Sampson, J.; Scott, R.; Burn, J.; Moslein, G.; et al. Lack of association between screening interval and cancer stage in Lynch syndrome may be accounted for by over-diagnosis; a prospective Lynch syndrome database report. Hered. Cancer Clin. Pract. 2019, 17, 8. [CrossRef] [PubMed]

55. Seppala, T.; Pylvanainen, K.; Evans, D.G.; Jarvinen, H.; Renkonen-Sinisalo, L.; Bernstein, I.; Holinski-Feder, E.; Sala, P.; Lindblom, A.; Macrae, F.; et al. Colorectal cancer incidence in path_MLH1 carriers subjected to different follow-up protocols: A Prospective Lynch Syndrome Database report. Hered. Cancer Clin. Pract. 2017, 15, 18. [CrossRef]

56. Hartman, D.J.; Nikiforova, M.N.; Chang, D.T.; Chu, E.; Bahary, N.; Brand, R.E.; Zureikat, A.H.; Zeh, H.J.; Choudry, H.; Pai, R.K. Signet ring cell colorectal carcinoma: A distinct subset of mucin-poor microsatellite-stable signet ring cell carcinoma associated with dismal prognosis. Am. J. Surg. Pathol. 2013, 37, 969-977. [CrossRef]

57. Dominguez-Valentin, M.; Seppala, T.T.; Sampson, J.R.; Macrae, F.; Winship, I.; Evans, D.G.; Scott, R.J.; Burn, J.; Moslein, G.; Bernstein, I.; et al. Survival by colon cancer stage and screening interval in Lynch syndrome: A prospective Lynch syndrome database report. Hered. Cancer Clin. Pract. 2019, 17, 28. [CrossRef]

58. Shia, J.; Schultz, N.; Kuk, D.; Vakiani, E.; Middha, S.; Segal, N.H.; Hechtman, J.F.; Berger, M.F.; Stadler, Z.K.; Weiser, M.R.; et al. Morphological characterization of colorectal cancers in The Cancer Genome Atlas reveals distinct morphology-molecular associations: Clinical and biological implications. Mod. Pathol. 2017, 30, 599-609. [CrossRef] [PubMed]

59. Alexandrov, L.B.; Nik-Zainal, S.; Wedge, D.C.; Aparicio, S.A.; Behjati, S.; Biankin, A.V.; Bignell, G.R.; Bolli, N.; Borg, A.; Borresen-Dale, A.L.; et al. Signatures of mutational processes in human cancer. Nature 2013, 500, 415-421. [CrossRef]

60. Oliveira, C.; Westra, J.L.; Arango, D.; Ollikainen, M.; Domingo, E.; Ferreira, A.; Velho, S.; Niessen, R.; Lagerstedt, K.; Alhopuro, P.; et al. Distinct patterns of KRAS mutations in colorectal carcinomas according to germline mismatch repair defects and hMLH1 methylation status. Hum. Mol. Genet. 2004, 13, 2303-2311. [CrossRef]

61. Zauber, P.; Marotta, S.; Sabbath-Solitare, M. KRAS gene mutations are more common in colorectal villous adenomas and in situ carcinomas than in carcinomas. Int. J. Mol. Epidemiol. Genet. 2013, 4, 1-10.

62. Juarez, M.; Egoavil, C.; Rodriguez-Soler, M.; Hernandez-Illan, E.; Guarinos, C.; Garcia-Martinez, A.; Alenda, C.; Giner-Calabuig, M.; Murcia, O.; Mangas, C.; et al. KRAS and BRAF somatic mutations in colonic polyps and the risk of metachronous neoplasia. PLoS ONE 2017, 12, e0184937. [CrossRef]

63. Hoffmeister, M.; Blaker, H.; Jansen, L.; Alwers, E.; Amitay, E.L.; Carr, P.R.; Kloor, M.; Herpel, E.; Roth, W.; Chang-Claude, J.; et al. Colonoscopy and Reduction of Colorectal Cancer Risk by Molecular Tumor Subtypes: A Population-Based Case-Control Study. Am. J. Gastroenterol. 2020, 115, 2007-2016. [CrossRef]

64. Shaukat, A.; Arain, M.; Anway, R.; Manaktala, S.; Pohlman, L.; Thyagarajan, B. Is KRAS mutation associated with interval colorectal cancers? Digest. Dis. Sci. 2012, 57, 913-917. [CrossRef]

65. Fearon, E.R.; Vogelstein, B. A genetic model for colorectal tumorigenesis. Cell 1990, 61, 759-767. [CrossRef]

66. Arnold, A.; Tronser, M.; Sers, C.; Ahadova, A.; Endris, V.; Mamlouk, S.; Horst, D.; Mobs, M.; Bischoff, P.; Kloor, M.; et al. Correction to: The majority of beta-catenin mutations in colorectal cancer is homozygous. BMC Cancer 2020, 20, 1151. [CrossRef]

67. Aaltonen, L.A.; Salovaara, R.; Kristo, P.; Canzian, F.; Hemminki, A.; Peltomaki, P.; Chadwick, R.B.; Kaariainen, H.; Eskelinen, M.; Jarvinen, H.; et al. Incidence of hereditary nonpolyposis colorectal cancer and the feasibility of molecular screening for the disease. N. Engl. J. Med. 1998, 338, 1481-1487. [CrossRef] [PubMed]

68. Maruvka, Y.E.; Mouw, K.W.; Karlic, R.; Parasuraman, P.; Kamburov, A.; Polak, P.; Haradhvala, N.J.; Hess, J.M.; Rheinbay, E.; Brody, Y.; et al. Analysis of somatic microsatellite indels identifies driver events in human tumors. Nat. Biotechnol. 2017, 35, 951-959. [CrossRef] [PubMed]

69. Roeckel, N.; Woerner, S.M.; Kloor, M.; Yuan, Y.P.; Patsos, G.; Gromes, R.; Kopitz, J.; Gebert, J. High frequency of LMAN1 abnormalities in colorectal tumors with microsatellite instability. Cancer Res. 2009, 69, 292-299. [CrossRef]

70. Lockwood, W.W.; Thu, K.L.; Lin, L.; Pikor, L.A.; Chari, R.; Lam, W.L.; Beer, D.G. Integrative genomics identified RFC3 as an amplified candidate oncogene in esophageal adenocarcinoma. Clin. Cancer Res. 2012, 18, 1936-1946. [CrossRef]

71. Woerner, S.M.; Benner, A.; Sutter, C.; Schiller, M.; Yuan, Y.P.; Keller, G.; Bork, P.; Doeberitz, M.; Gebert, J.F. Pathogenesis of DNA repair-deficient cancers: A statistical meta-analysis of putative Real Common Target genes. Oncogene 2003, 22, $2226-2235$. [CrossRef] [PubMed]

72. Lai, E.J.; Calderwood, A.H.; Doros, G.; Fix, O.K.; Jacobson, B.C. The Boston bowel preparation scale: A valid and reliable instrument for colonoscopy-oriented research. Gastrointest. Endosc. 2009, 69, 620-625. [CrossRef]

73. Lappalainen, J.; Holmstrom, D.; Lepisto, A.; Saarnio, J.; Mecklin, J.P.; Seppala, T. Incident colorectal cancer in Lynch syndrome is usually not preceded by compromised quality of colonoscopy. Scand. J. Gastroenterol. 2019, 54, 1473-1480. [CrossRef] [PubMed]

74. Haanstra, J.F.; Vasen, H.F.; Sanduleanu, S.; van der Wouden, E.J.; Koornstra, J.J.; Kleibeuker, J.H.; de Vos Tot Nederveen Cappel, W.H. Quality colonoscopy and risk of interval cancer in Lynch syndrome. Int. J. Colorectal Dis. 2013, 28, 1643-1649. [CrossRef] [PubMed] 